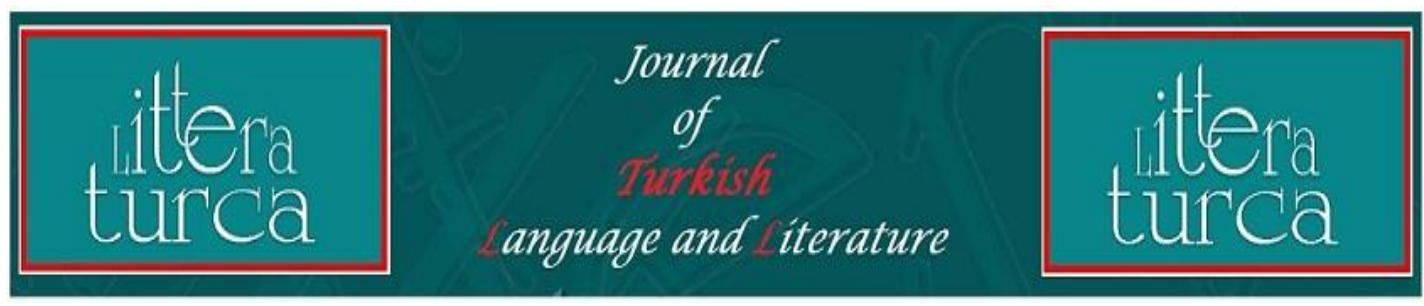

\title{
TÜRKÇEDE ANA DIL VE ANA DILI
}

\section{Şerif ORUÇ}

Özet

Bu makalede "ana dil" ve "ana dili" terimlerinin anlamları ve farkları verilecektir. Kullanımlarında meydana gelen karmaşa ve hatalar ortaya konularak doğru kullanım önerileri sunulacaktır. Her iki kavramın dilimizde ve Batı dillerinde sözlük karşılıklarını ve tanımlarını vererek aralarındaki farkı ortaya koyacağız. Kavramların birbirlerinin yerine kullanıldıklarını, bazen ikisi arasında görüntü olarak bir farkın bulunmadığın örneklendireceğiz. iki kavram arasındaki karışıklığın ve hatalı kullanımın en çok hal ekleri ve iyelik ekleri ile birlikte kullanılırken meydana geldiğini tespit ederek örneklerle daha anlaşılır hale getireceğiz.

Son olarak "ana dil" ve "ana dili" kavramlarının yerine önerdiğimiz "birinci dil" ve "ikinci dil" kavramlarının açıklamalarını yaparak kullanımıyla ilgili somut örneklerle savunduğumuz tezimizi güçlendireceğiz. Çağdaş ve gelişmiş devletler arasında özellikle Avrupa Birliği üyesi devletler arasında "birinci dil" ve "ikinci dil" kavramlarının kabul gördüğünü ve Avrupa Birliğine üye olmak için hızlı adımlarla ilerleyen ülkemizde de bu kavramların aynı anlamda kullanılmasının uygun olacağını bu yazımızda anlatmaya çalıştık.

Anahtar Kavramlar: Ana dil, ana dili, birinci dil, ikinci dil, dil gelişimi, dil kullanımı.

\section{MAIN LANGUAGE AND MOTHER LANGUAGE IN TURKISH}

\begin{abstract}
In this study, the meanings of the terms "main language" and "mother tongue" and their differences are addressed. Correct uses of the terms are presented through an analysis of the ambiguities and errors stemming from their uses. We aim to explore the differences between these two terms by giving their literal meanings and definitions in both our language and west languages. We exemplify that these two terms are used interchangeably and there are no basic differences between these two terms. We explain that incorrect uses of the terms and ambiguities are due to the cases and possessive cases, some of which will be exemplified in the paper.

Finally, we aim to strengthen our argument by proposing such terms as "first language" and "second language" instead of "main language" and "mother tongue" and give certain concrete examples of their uses in the languages. Terms "first language" and "second language" are widely accepted and employed in modern and developed countries specifically in European Union countries. We conclude our paper by saying that it is better to use these terms in our country, which is advancing at a rapid rate towards the European Union.
\end{abstract}

Keywords: Main language, mother language, first language, second language, language development, language use..

\footnotetext{
1 Yrd. Doç. Dr., Gazi Üniversitesi, Eğitim Fakültesi, Yabancı Diller Eğitimi Bölümü, Alman Dili Eğitimi Ana Bilim Dalı,
} soruc@gazi.edu.tr.

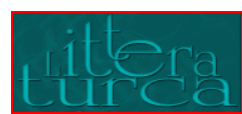




\section{Giriş}

Dil insanlar arasında anlaşmayı sağlayan temel kurucu öğedir. İnsan öncelikle kendi dilinin içine doğar ve böylece kendi varlık alanını oluşturur. Dil, kişinin varlık alanının ses, yazı ve beden diline dönüşmüş halidir. Her millet ve onu oluşturan bireyler, kendi dil evreninde kimlik kazanır. Bu açıdan dil, maziden gelen kıymetlerin, zihniyet ve psikolojinin, fert ve cemiyetin bir ifadesidir. Şahin (2014: 828). Dil aynı zamanda ulus ve millet kavramlarının da oluşmasını sağlayan temel kurucu öğedir.

Ülkemizde son zamanlarda sıklıkla rastladığımız Ulus ve Millet kavramlarının aynı anlamı ya da farklı anlamı taşıdığı konusunda yapılan tartışmaların yanında "ana dil” ve "ana dili" kavramlarının da günümüz halk dilinde, yani günlük konuşma dilinde, kitaplarda, makalelerde, görsel ve yazılı basında çoğunlukla yanlış kullanıldığı görülmektedir. Bu yanlışlık daha çok "ana dil" kavramının "ana dili" kavramı yerine kullanılması şeklinde karşımıza çıkmaktadır, daha açık bir şekilde ifade edersek "ana dil” kavramı "ana dili" kavramı yerine kullanılmakta hatta iki sözcük eş anlamlı olarak kullanılmaktadır. Her iki sözcüğün doğru bir biçimde kullanılmasına ancak uzmanlık alanı dil, dilbilim, dil bilgisi, dil ve edebiyat vb. olan kişilerde rastlıyoruz.

Bu yazımızda "ana dil" ve "ana dili" sözcüklerinin tanımlarını vererek birbirlerinden farklı anlam taşıdıklarını, birbirlerinin yerine eş anlamlı olarak kullanılamayacağını, Batı dillerinde aynı kavramların nasıl yer aldığını ve bu dillerde de Türkçede olduğu gibi bir kargaşanın olup olmadığını ortaya koyduktan sonra her iki kavramın doğru kullanılması konusunda önerilerde bulunacağız.

"Ana dil” ve "ana dili" kavramlarında karışıklığa ve yanlış kullanılmaya neden olan sözcüğün “ana” sözcüğü olduğunu öncelikle belirtmeliyiz. "ana” sözcüğü karşılığı olarak Türk Dil Kurumu Büyük Türkçe Sözlükte (http://tdkterim.gov.tr/bts/) " 1. Anne. 2. Yavrusu olan dişi hayvan. 3. Dinî bakımdan aziz tanınan bazı kadınlara verilen saygı unvanı. 4. ünl. Yaşlı kadınlara saygılı bir seslenme sözü. 5. Velinimet. 6. Alacağın veya borcun, faizin dışında olan bölümü. 7. sf. Temel, asıl, esas. 8. mat. Çizgilerden herhangi birini anlatan kelimeye sıfat olarak geldiğinde o çizginin, belirli bir kural altında hareket ederek bir yüzey oluşturmaya yaradığını anlatan bir söz." tanımları yer almaktadır. "Ana dil” kavramındaki "Ana” sözcüğünün karşılığı Türk Dil Kurumu Büyük Türkçe Sözlükteki ana sözcüğünün 7. anlamı, yani “temel, asıl, esas” sözcükleridir. "Ana dili” kavramındaki "Ana” sözcüğünün karşılığı ise 1. anlam, yani “anne" sözcüğüdür. Dolayısıyla "ana dil” kavramına eş veya yakın anlam olarak "temel dil, asıl dil, esas dil" diyebiliriz. "Ana dili" kavramına ise şimdilik Mukim Sağır’ın "Ana dil mi, Ana dili mi?" adlı makalesinde dediği gibi "anne dili" diyebiliriz.

"Ana dil” ve "ana dili" kavramlarının şimdi de Batı dillerindeki karşılıklarına bakalım. "Ana dil” kavramındaki "ana (temel, asıl, esas)" Almancada "Ur-, Haupt, Grund", Fransızcada "mère", İngilizcede "main, major" sözcükleriyle karşılık bulmaktadır. Buradan hareketle “ana dil” kavramının sözcük olarak karşılığı Almancada "Ursprache, Hauptsprache", Fransızcada "langue mère", İngilizcede "primitive language, native language, main language" şeklindedir. "Ana dili” kavramının sözcük karşılığı ise Almancada "Muttersprache”, Fransızcada

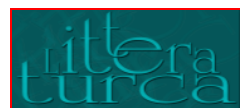


"langue maternelle", İngilizcede "mother tongue, mother language" şeklinde karşımıza çıkmaktadır. "Ana dil” ve "ana dili" kavramlarını aynı şekilde Almancada "Ursprache (Hauptsprache) und Muttersprache", Fransızcada "langue mère et langue maternelle", İngilizcede "main language and mother tongue" olarak verdiğimizde Batı dillerinde tamamen iki farklı sözcükten meydana gelen "Ana” sözcüğü herhangi bir karışılığa meydan vermezken, Türkçede "ana" sözcüğünün hem "anne" hem de "temel, asıl, esas" sözcüklerini içinde barındırması karışıklığa, yanlış kullanmaya neden olmaktadır. Şimdi sırasıyla "ana dil" ve "ana dili" kavramlarının hem Türkçede hem de Batı dillerinde tanımlarını verelim.

\section{Ana dil:}

"Ana dil" kavramındaki ana sözcüğü burada anne anlamında değil, kaynak, temel, asıl, esas hatta ortak anlamında kullanılmaktadır. Dolayısıyla "ana dil” kavramı için içinde başka diller barındıran kaynak dil, birkaç dile temel oluşturan dil, birden çok dilin aslını kökenini oluşturan dil tanımını yapabiliriz.

Türk Dil Kurumu Büyük Türkçe Sözlükte (2005: 93) "ana dil”: "Kendisinden başka diller veya lehçeler türemiş olan dil."olarak yer almaktadır.

Dil Bilim Terimleri Sözlüğünde(http://www.tdk.gov.tr) "ana dil” için: "Başka diller türetmiş olan eski dil."denmektedir.

Gramer Terimleri Sözlüğünde: “Bugün ses yapısı, şekil yapısı anlam bakımından birbirinden az çok farklılaşmış bulunan dil veya lehçelerin, kök bakımından bilinmeyen bir tarihte birleştikleri ortak dil: Ana Türkçe, Ana Moğolca, Ana Altayca, Roman dillerinin temeli Latince gibi." (Korkmaz (1992: 8)

Açıklamalı Dil Bilim Terimleri Sözlüğünde Vardar (1988: 20) "ana dil” kavramını: "Bir veya birden çok dilin kaynaklandığı dil. Örneğin Latince gibi." tanımlıyor.

Dil Bilgisi Terimleri Sözlüğünde Topaloğlu (1989: 24) “ana dil” için: “Akraba oldukları kabul edilen dillerin aslını kaynağını oluşturan dil. Altay dili Türkçe, Moğolca ve Mançu-Tunguzcanın ana dili kabul edilir. Latince Roman dillerine göre bir ana dildir" demektedir.

Türk Dil Bilgisi kitabında Ergin (2000: 9) Türkçenin ana dil olduğunu: “Ural-Altay dillerinin Altay kolunda ise şu diller vardır: Mançuca, Moğolca, Türkçe." sözleri ile vurgulamaktadır. Ayrıca Ergin'e (2000: 15-26) göre Türkçe, ilk yazılı şeklini Orhun Abidelerinde gördüğümüz ve tarih boyunca Asya ve Avrupa'da yaşayan Türk Boyları, Kavimleri ve Devletleri tarafından kullanılan Eski Türkçe, Kuzey Türkçe, Doğu Türkçe, Batı Türkçe, Azeri Türkçesi, Osmanlı Türkçesi, Türkiye Türkçesi gibi dillere kaynaklık etmiştir. Bir başka ifadeyle Türkçe Oğuzca, Uygurca, Çağatayca, Özbekçe, Azerice gibi dillerin kaynak dilidir.

Gencan (1997: 34) Dilbilgisi kitabında Türkçenin Ural-Altay dillerinin Altay kolundan geldiğini belirtiyor, aynı zamanda Türkçeyi Ana Türkçe olarak adlandırıyor. Ana Türkçe'den gelen dillerin hepsine Türk dilleri adını veriyor. Ana Türkçe içindeki dilleri de Göktürkçe, Uygurca, Kıpçakça, Çağatayca (Özbekçe), Azerice ve Anadolu

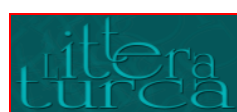


Türkçesi v.b. olarak saymaktadır. Hengirmen (1999: 25) ise "ana dil” tanımını " birden çok dile kaynaklık eden dil, akraba dillerin türediği dil” olarak vermektedir.

Almanca “Ursprache ( kaynak dil, ana dil)" kavramının tanımı Almanca Sözlükte Wahrig (1980: 3917) : "Birçok dilin ortak özelliklerinin yer aldığı eski dil."olarak tanımlamaktadır.

Almanca "Hauptsprache (ana dil)" kavramının tanımı Wiki sözlüğünde (http://de.wiktionary.org/wiki/Hauptsprache) : “1) Eski dil anlayışına göre kendisinden başka dillerin geliştiği, türediği önemli dillerden biri, 2) Çok dilli bir çevrede özellikle önemli olan, öne çıkan dil, 3) Çok dilli bir kişinin düşüncelerini, kendisini ifade ettiği dil." şeklinde yer almaktadır.

"Ana dil” tanımlarını Türkçe kaynaklardaki ile Batılı kaynaklardaki anlam olarak karşılaştırdığımızda birbirlerine çok yakın anlamlar içerdiğini söyleyebiliriz. Bu tanımlardan yola çıkarak "ana dil” : 1. Kaynak dil olarak, içinde birden fazla dil barındırabilir, 2. Eski, köklü bir dil olarak bazı dillerin türediği ölü dil olabilir.

\section{Ana dili:}

"Ana dili" kavramındaki ana sözcüğü doğrudan anne ile ilgili olduğu için en kısa tanımıyla, kişinin annesinden öğrendiği dil anlamına gelmektedir. Biraz daha geniş anlamda bir tanım yapılacak olursa da "ana dil” için kişinin annesinden, ailesinden, sosyal çevresinden doğal yolla ilk edindiği, en iyi kullandığı ve hâkim olduğu dildir diye tanımlayabiliriz.

Gramer Terimleri Sözlüğünde Korkmaz (1992:8): “Insanın doğup büyüdüğü aile ve bağlı bulunduğu toplum çevresinden edindiği, kendisiyle toplum arasındaki ilişkilerde en güçlü bağı oluşturan dil”,

Açıklamalı Dil Bilim Terimleri Sözlüğünde Vardar (1988: 20):" Kişinin ailede ve içinde büyüdüğü toplumda edindiği ilk dildir.",

Dil Bilgisi Terimleri Sözlüğünde Topaloğlu (1989: 24): “Kişinin önce annesinden ve diğer aile fertlerinden, sonra içinde bulunduğu sosyal çevreden edindiği, kendisiyle toplum arasındaki iletişimi sağlayan dil" olarak tanımlamaktadır.

Aksan (1990:81) 'Ana dili' tanımını "başlangıçta anneden ve yakın aile çevresinden, daha sonra da ilişkili bulunulan çevrelerden öğrenilen, insanın bilinçaltına inen ve bireylerin toplumla en güçlü bağlarını oluşturan dildir.. Adından da görüleceği gibi, bu dilin anne ile ilgisi, küçümsenemeyecek niteliktedir. ... Bununla birlikte kimi bilginler, anadili kavramında annenin temel olarak alınmaması gerektiği görüşündedirler.. Ancak bu bilginlerin de anadili tanımlarında yakın çevreye önem verdikleri görülür ki, ananın bu çevrenin odak noktası olarak düşünülmesi doğaldır." şeklinde yapmaktadır.

Demircan (1990: 14) "ana dili" kavramı için, insanın çevresiyle olan ilişkilerinde algıladığı iletişim verilerini işleyerek, yaşamının ilk birkaç yılı içinde edindiği dil, birinci dildir demektedir. Koç (1992: 28) ana dilini, önce anneden ve yakın çevreden, sonra daha geniş çevreden ve ulusal olanaklardan

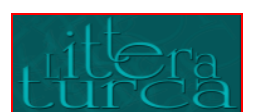


yararlanarak öğrenilen dil olarak görmektedir. Ayrıca her Türkün ana dilinin Türkçe olduğunu söylemektedir. Bu ifade kâğıt üzerinde doğru gibi görünse de ileride açıklayacağımız nedenlerden dolayı tam doğru değildir.

Almanca "Muttersprache (ana dili)" kavramının tanımı Almanca Wahrig (1980):2613) isimli sözlükte: “Çocukluktan itibaren öğrenilen dil.”, yine Almanca Duden isimli Sözlükte (1985:453) : “Çocukken öğrenilen dil, ilk kullanılan dil, birinci dil." Olarak yer almaktadır. Oomen-Welke (2007: 578), Bausch/Christ/Krumm (2007 ) üçlüsünün Yabancı Dil Öğretimi El Kitabı’nda (Handbuch Fremdsprachenunterricht) yer alan "Ana Dili ve Yabancı Dil Öğretimi (Muttersprachen- und Fremdsprachenunterricht)" başlıklı makalesinde "ana dili" kavramını "kişinin birinci dili, yani konuşmayı ve düşünmeyi öğrendiği dil, doğal bir yolla edindiği ve en iyi hâkim olduğu dil” olarak tanımlamaktadır. Bütün bu tanımlardan da anlaşıldığı gibi Türkçedeki "ana dil” ve "ana dili" kavramları arasındaki karmaşa ve yanlış kullanım sadece "ana" sözcüğünün Batı dillerinden farklı olarak hem "anne" hem de "temel, asıl, esas" anlamı taşımasından kaynaklanıyor. " Ana dilde eğitim, her vatandaşın kendi ana dilini öğrenmesi, ana dilin kuralları, kişilerin kendi ana dillerinde eğitim hakkının olması" gibi ifadeleri son zamanlarda sıkça duyuyoruz. Bu ifadeleri kullananların hangi kavramı, yani "ana dil” mi yoksa "ana dili" mi kastettiği tam olarak anlaşılamıyor. Ülkemizde etnik kökeni farklı olan bir Türk vatandaşı örneğin Kürt veya Arap kökenli bir Türk vatandaşı "ana dilde eğitim hakkı istiyorum" dediğinde biz onun Kürtçe veya Arapça dilinde eğitim yapmak istediğini anlıyoruz. Ancak bu kişinin ifadesi “ ana dilinde eğitim hakkı istiyorum” olmalıdır. Aynı ifadeyi devlet kurumu açısından örneklendirirsek "Anayasamız, etnik kökeni farklı olan vatandaşlarımıza ana dilde eğitim izni vermiyor” diyen bir Milli Eğitim Bakanı yanlış ifade kullanmış oluyor. Doğrusu “ana dilinde eğitim” olmalıdır.

Ana dil ve ana dili kavramlarının kullanımında en sık rastlanılan hatalar konuşma ve yazı dilinde bu kavramlara eklenen hal ekleri ve iyelik ekleri ilavesi ile ortaya çıkmaktadır. Şimdi sırasıyla her iki kavramı hal eklerini kullanarak gösterelim:

Tablo 1. Hal Ekleri

\begin{tabular}{|c|c|c|c|c|}
\hline Hal Ekleri & \multicolumn{2}{|c|}{ Ana Dil } & \multicolumn{2}{|c|}{ Ana Dili } \\
\hline Nominatif Hali (Yalın Hal) & $\begin{array}{l}\text { (Tekil) Ana } \\
\text { (Çoğul) Ana }\end{array}$ & & $\begin{array}{l}\text { (Tekil) Ana Di } \\
\text { (Çoğul) Ana Di }\end{array}$ & \\
\hline $\begin{array}{l}\text { Genitif Hali (İlgi Hali) -ın,-in,-un, - } \\
\text { ün, -nın,-nin,-nun,-nün }\end{array}$ & $\begin{array}{l}\text { Ana Dilin } \\
\text { Ana Dillerin }\end{array}$ & $\begin{array}{l}\text {-in } \\
\text {-in }\end{array}$ & $\begin{array}{l}\text { Ana Dilinin } \\
\text { Ana Dillerinin }\end{array}$ & $\begin{array}{l}-\operatorname{nin} \\
-\operatorname{nin}\end{array}$ \\
\hline $\begin{array}{l}\text { Akuzatif Hali (Yapma hali) -ı, -i, -u, } \\
-\ddot{u},-n ı,-n i,-n u,-n u ̈\end{array}$ & $\begin{array}{l}\text { Ana Dili } \\
\text { Ana Dilleri }\end{array}$ & $\begin{array}{l}-i \\
-i\end{array}$ & $\begin{array}{l}\text { Ana Dilini } \\
\text { Ana Dillerini }\end{array}$ & $\begin{array}{l}-\mathrm{ni} \\
-\mathrm{ni}\end{array}$ \\
\hline Datif Hali (Yaklaşma Hali) -a, -e & $\begin{array}{l}\text { Ana Dile } \\
\text { Ana Dillere }\end{array}$ & $\begin{array}{l}-e \\
-e\end{array}$ & $\begin{array}{l}\text { Ana Diline } \\
\text { Ana Dillerine }\end{array}$ & $\begin{array}{l}-(n) e \\
-(n) e\end{array}$ \\
\hline Lokatif Hali (Bulunma Hali) -de, - & Ana Dilde & -de & Ana Dilinde & -(n)de \\
\hline
\end{tabular}

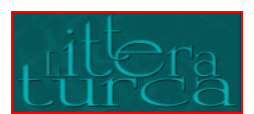




\begin{tabular}{|l|ll|l|}
\hline da, -te, -ta & Ana Dillerde -de & Ana Dillerinde $\quad$-(n)de \\
\hline Ablatif Hali (Uzaklaşma Hali) -den, & Ana Dilden $\quad$-den & Ana Dilinden $\quad-(\mathrm{n})$ den \\
-dan, -ten, -tan & Ana Dillerden -den & Ana Dillerinden -(n)den \\
\hline
\end{tabular}

Hal ekleri için Ergin'in (2000: 226-236) Türk Dil Bilgisi adlı kitabından yararlanılmıştır.

Yukarıda ki tabloda "ana dil" kavramının Akuzatif hali (ana dili) ile "ana dili" kavramının Nominatif halinin (ana dili) yazım ve sesletim şeklinin aynı olduğunu görüyoruz. Diğer durumlarda ise ikisi arasında en azından yazım ve sesletim bakımından bir harfin, bir sesin farklı olduğu görülüyor. Örneklendirelim:

1. Ana dil eşittir kaynak dil, temel dil.

2. Ana dili eşittir anne dili.

3.Türkiye'de herkes ana dili (Türkçe) öğrenir.

4.Türkiye'de herkes ana dilini (Kürtçe, Arapça gibi) kullanabilir. (Akuzatif, -i hali)
(Nominatif, yalın)

(Nominatif, yalın)

(Akuzatif, -i hali)

2 ve 3 numaralı örneklerde kavramın yazılışı ve söylenişi aynı, görüntü olarak her iki kavram birbirinin kopyası, fakat cümle içindeki hem konumları hem de görevleri farklı, en önemlisi anlamları farklıdır. 2 numaralı örnekte ana dili (anne dili) kavramı, 3 numaralı örnekte ana dil (kaynak dil, temel dil) kavramı kullanılmıştır. Bu durum özellikle konuşma dilinde karışıklığa, yanlış kullanıma neden olmaktadır. Konuyu biraz daha derinleştirdiğimizde bu iki kavramın ad tamlamalarında daha da karıştığı görülmektedir. Ad tamlamalarında bilindiği üzere bir tamlayan bir de tamlanan vardır. Birinci sıradaki ad tamlayan ikinci sıradaki ad tamlanandır. Tamlayan ad'a gelen ek -ın,-in,-un,-ün tamlanan ad'a gelen ek -ı,-i,-u,-ü olur. Bazen ad tamlamalarında tamlayan ek almaz sadece tamlanan ek alır, bazen de her iki ad yani tamlayan da tamlanan da ek almaz. Bizim ele aldığımız "ana dil" ve "ana dili" kavramlarını ad tamlamaları yaparak hatta ad tamlaması içinde hem tamlayan hem de tamlanan olarak örneklendirelim: Kavramların tamlayan olarak örneklendirilmesi:

Ana Dil

Tekil: Ana dilin kuralı

Çoğul: Ana dillerin kuralları
Ana Dili

Ana dilinin kuralı

Ana dillerinin kuralları

Şimdi de tamlanan olarak örneklendirelim:

Tekil: Öğrencinin ana dili

Çoğul: Öğrencilerin ana dilleri
Öğrencinin ana dili

Öğrencilerin ana dilleri

Kavramların tamlayan olarak kullanımında konuşma dilinde, yani sözel olarak ifade edilmesinde karışıklık olma intimali olmasına rağmen yazı dilinde yukarıda da görüldüğü gibi aralarındaki fark açık bir biçimde

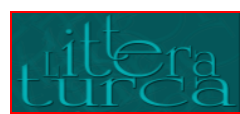


görülmektedir. Konuşma dilindeki karışıklık ise bazen kişilerin söyleyiş kolaylığına kaçarak, bazen de hızlı konuşurken hecelerin veya eklerin yutularak söylenmemesinden kaynaklanmaktadır. "ana dil" ve "ana dili" kavramlarının tamlanan olarak söylenmesinde ve yazılmasında yukarıda görüldüğü gibi herhangi bir fark yok, her ikisi de görüntü olarak birbirinin aynısı. Fakat iki kavram anlam olarak birbirinden farklıdır.

"Ana dil" ve "ana dili" kavramlarının iyelik ekleriyle kullanılmalarında hal eklerine göre çok daha fazla karışıklık ve hatalar meydana geldiğini görmekteyiz. Bunu daha yakından göstermek için de bu iki kavramın iyelik ekleri ile çekimlerini bir tabloda verelim:

Tablo 2. İyelik Ekleri

\begin{tabular}{|c|c|c|c|c|c|c|}
\hline \multirow{2}{*}{ Tekil } & \multicolumn{2}{|c|}{ İyelik Ekleri } & \multicolumn{2}{|c|}{ Ana Dil } & \multicolumn{2}{|c|}{ Ana Dili } \\
\hline & 1.Şahıs & $-m$ & Ana Dilim & $-(i) m$ & Ana Dilim & $-m$ \\
\hline & 2.Şahıs & $-n$ & Ana Dilin & $-(i) n$ & Ana Dilin & $-n$ \\
\hline & 3.Şahıs & $\begin{array}{l}-ı,-i,-u,-\ddot{u} ;-s ı \\
-s i,-s u,-s u ̈\end{array}$ & Ana Dili & $-\mathrm{i}$ & Ana Dili & - \\
\hline \multirow[t]{3}{*}{ Çoğul } & 1.Şahıs & $\begin{array}{l}-m ı z,-m i z, \\
-m u z,-m u ̈ z\end{array}$ & Ana Dilimiz & -(i)miz & Ana Dilimiz & $-\mathrm{miz}$ \\
\hline & 2.Şahıs & $\begin{array}{l}\text {-nız, -niz, } \\
\text {-nuz, -nüz }\end{array}$ & Ana Diliniz & -(i)niz & Ana Diliniz & $-n i z$ \\
\hline & 3.Şahıs & -ları, -leri & Ana Dilleri & -leri & Ana Dilleri & -leri \\
\hline
\end{tabular}

İyelik ekleri için Ergin'den (2000:222) ve Gencan'dan (1997:130) yararlanılmıştır.

Yukarıdaki tabloda da görüldüğü gibi her iki kavramın iyelik ekleri ile kullanımlarında hem tekil hem de çoğul durumlarında hiçbir fark görülmemektedir. Bu tür kullanımlarda kavram olarak "ana dil” mi yoksa "ana dili" mi kastediliyor belli değildir. Her iki kavram birbirinin yerine kullanılabiliyor, bu da yanlışlıklara, kullanım hatalarına ve yanlış anlamalara yol açabiliyor. Daha iyi anlaşılması için bunları da örneklendirmekte fayda var. Hepimizin bildiği gibi Türkiye sınırları içinde yaşayan herkes Türk vatandaşıdır, fakat Türk değildir. Çünkü Türkiye sınırları içinde yaşayan Türk vatandaşları arasında etnik kökeni farklı olan Rumlar, Ermeniler, Araplar, Kürtler vb. gibi birçok topluluklar vardır. Bunların hepsi Türk vatandaşıdır ve dilleri de Türkiye Cumhuriyeti Devletinin Anayasasında yazdığı gibi Türkçedir. Yazımızın kavram açıklaması bölümünde Türkçenin bir ana dil olduğunu yazmıştık. Buna göre Türkiye'de yaşayan bütün Türk vatandaşlarının ana dili Türkçedir, yani Türkiye'de konuşulan kullanılan birçok dil vardır, fakat ana dil Türkçedir. Burada hemen etnik kökeni farklı olan Türk vatandaşları itiraz edebilir. Ancak etnik kökeni her ne olursa olsun bütün Türk vatandaşlarının birbiriyle anlaştığı, konuştuğu ortak dil, anayasada belirtilen dil, ülke dili, resmi dil, temel dil, kaynak dil adına "ana dil" dediğimiz kavramla örtüşmektedir. Buna ilave olarak ülkede yaşayan ve çoğunluğu oluşturan etnik kökeni Türk olan Türk vatandaşlarının hem "ana dilleri (ana dil)" hem de "ana dilleri (ana dili)" Türkçedir. Etnik kökeni

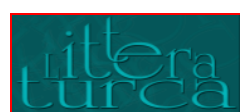


Ermeni olan Türk vatandaşlarının "ana dilleri (ana dil)" Türkçe, "ana dilleri (ana dili)" ise Ermenicedir. Etnik kökeni Arap olan Türk vatandaşlarının "ana dilleri (ana dil)" Türkçe, "ana dilleri (ana dili)" ise Arapçadır. Yine etnik kökeni Kürt olan Türk vatandaşlarının "ana dilleri (ana dil)" Türkçe, "ana dilleri (ana dili)" ise Kürtçedir. Bu durum ülkemizde yaşayan etnik kökeni farklı diğer Türk vatandaşları için de aynıdır. Yani ortak "Ana dil” Türkçe, "Ana dili" ise etnik kökene göre farklılık göstermektedir.

Yukarıda örneklerle anlatmaya ve somut delillerle açıklamaya çalıştığımız "ana dil" ve "ana dili" kavramlarının birbirine ne kadar yakın olduğunu, karıştırılmaya ne kadar müsait olduğunu ve yanlış anlamalara ne kadar çok yol açtığını gördük ve tespit ettik. Hatta son zamanlarda ülkemizde yeni anayasa yapma çalışmaları sırasında siyasi figürler tarafından "ana dil” ve "ana dili” kavramlarının sıklıkla yanlış kullanıldığına şahit olmaktayız. Böyle bir durumda dilcilerin, dilbilimcilerin ve özellikle devletin resmi kurumu Türk Dil Kurumu'nun (TDK) bu soruna bir çözüm bulması, bu karışıklığı gidermesi ve her iki kavramın birbirinin yerine yanlış kullanılmasını önlemesi gerekmektedir. Yazımızın baş tarafında da belirttiğimiz gibi bu konuda makalesi olan Mukim Sağır "ana dil ve ana dili" kavramlarını birbirinden ayırmak için "ana dili" kavramı yerine "anne dili" kavramını önermektedir. Fakat aşağıda açıklayacağımız nedenlerden dolayı bu önerinin de kavramı tam karşılamadığını ve yetersiz kaldığını göreceğiz. "ana dili” kavramının tanımı her ne kadar "kişinin annesinden, doğup büyüdüğü çevrede öğrendiği dil” ise de gelişen ve küreselleşen dünyada uzaklıkların yakın olduğu, göçlerin yoğunlaştığı, ülkeler arası sınırların özellikle Avrupa Birliği üyesi ülkelerin sınırlarının neredeyse kalktığı günümüz dünyasında "ana dili" kavramını "anne dili" kavramı tam olarak karşılamamaktadır. Çünkü "ana dili" kavramını bazı dilciler "kişinin kendisini en rahat, en iyi ifade ettiği dil" olarak da tanımlamaktadırlar. Ülkemizde yaşayan bazı Arap ve Kürt kökenli vatandaşlar çocuklarına onların gelecekte öğrenim ve meslek hayatlarında zorluk çekmemeleri adına kendi dillerini değil doğrudan Türkçe öğretmektedirler. Böyle yetişen birinin "ana dili" her ne kadar etnik kökenine göre Kürtçe veya Arapça olsa da Kürtçe veya Arapçayı öğrenmemeleri nedeniyle kullanamadıklarından yukarıdaki tanıma göre kendilerini en iyi ifade ettikleri dil Türkçe olduğu için bu kişilerin "ana dili" Türkçe diyebiliriz. Bugün ülkemizde etnik kökeni Arap, Kürt, Laz, Çerkez olan Türk vatandaşları arasında kendi ana dilini, etnik köken dilini yani biyolojik anlamda "anne dilini” bilmeyen veya kullanacak kadar veya kendini ifade edecek kadar bilmeyen birçok kişi var. Şimdi bu kişilerin ana dilinin, bilmedikleri ve kullanamadıkları halde sadece biyolojik nedene bağlı olarak annelerinin dili olan Arapça, Kürtçe, Lazca, Çerkezcedir dememiz ne kadar doğru olur. Bir başka deyişle kişinin "ana dili” yani annesinin dili Arapça, Kürtçe olmasına rağmen kendisi annesinden ve ailesinden bu dili öğrenmemiş, aksine ailesinin desteği ve yardımıyla içinde bulunduğu toplumun kullandığı Türkçeyi hem çevresinden hem de okuldan öğrenmiş. Şimdi bu kişinin "ana dili" biyolojik bağdan dolayı anne dili Arapça veya Kürtçe midir yoksa bildiği kullandığı dil olan Türkçe midir? Elbette kişinin bilmediği dil için onun ana dilidir demek mümkün değildir. Bu konudaki örnekleri çoğaltmak mümkün, ancak verilen örneklerin her iki kavram arasında bir karmaşanın, yanlış kullanımın olduğunu göstermesi açısından yeterli olduğu kanaatindeyiz.

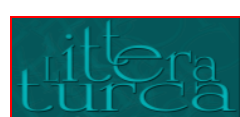




\section{Sonuç ve Öneriler}

Sonuç olarak "ana dil" ve "ana dili" kavramlarının yanlış kullanımlarını önlemek için farklı isimler önermek istiyoruz. "ana dili (anne dili)" kavramı yerine, kişinin doğar doğmaz duyup öğrenmeye başladığı ilk dil, birinci dil olduğu için "birinci dil” kavramını kullanmayı öneriyoruz. Çünkü "ana dili" kavramı tanımında birçok sözlük ve hemen hemen bütün dilbilimciler "ilk dil, birinci dil” ifadelerini kullanıyorlar. Yukarıda bizim de alıntıladığımız “ana dili” kavramı tanımında Dil Bilim Terimleri Sözlüğünde Vardar (1988: 20): Kişinin ailede ve içinde büyüdüğü toplumda edindiği ilk dildir ifadesini kullanmaktadır. Yine Almanca Duden (1985: 453) sözlüğünde: Çocukken öğrenilen dil, ilk kullanılan dil, birinci dil denmektedir. Demircan (1990:15-16) "ana dili" kavramı için “ilk dil, birinci dil" tanımını yapmaktadır. Klein (1984) İkinci dil edinimi - Bir giriş (Zweitspracherwerb - Eine Einführung) adlı kitabında sıklıkla "ana dili" için "birinci dil” kavramını kullanmaktadır. Yine Bausch/Christ/Krumm (2007) yayınladıkları Yabancı Dil Öğretimi El Kitabı'nda (Handbuch Fremdsprachenunterricht) birçok yerde "ana dili" kavramı için "birinci dil” karşılığı kullanılmaktadır.

Avrupa Birliği'ne üyelik sürecinde olan ülkemiz Avrupa Birliği Dil, Eğitim ve Öğretim Programlarına üyedir. Avrupa Birliği Dil Programlarında "ana dili” kavramı için "birinci dil” karşılığı kullanılmaktadır. Yani Avrupa Birliği ile bütünleşmeyi ve tam üyelik statüsünü kazanmayı hedefleyen ülkemizin de bu kavramı kullanıp yerleştirmeye çalışması kaçınılmazdır.

"Ana dil” yani yukarıda da tanımlarını verdiğimiz gibi “ kaynak dil, temel dil, ortak dil” olarak adlandırılmıştı. Ülkemizde de bu dilin Türkçe olduğunu belirtmiştik. Aynı zamanda anayasamızda da ülke dilinin Türkçe olduğu yazmaktadır. Birçok ülke anayasasında da durum hemen hemen aynıdır. Yani ülkede yaşan nüfusun çoğunluğunu meydana getiren etnik kökene sahip olanların dili ülke dili veya resmi dil veya eğitim dili olarak adlandırılmaktadır. Ülkemizde de nüfusun çok büyük bir çoğunluğunu meydana getiren Türklerin dili olan Türkçe ülke dili, resmi dil ve eğitim dili olarak anayasada yerini almıştır. Bütün bunlardan yola çıkarak "ana dil” kavramı için "resmi dil, ülke dili, ortak dil” kavramlarını kullanabiliriz. Kavramlardaki karmaşayı ve yanlış kullanmayı bu tür adlandırma ile aşabiliriz. Ancak bizim önerimiz Avrupa Birliği Dil, Eğitim ve Öğretim Programlarına da uygun olması için “ikinci dil” kavramının kullanılması olacaktır. “ikinci dil” kavramı bazen "yabancı dil" kavramı yerine kullanılmaktadır. Bu kullanım bazen doğru olsa da bazen de yanlış olmaktadır. Çünkü son zamanlarda ülkeler arası turizmin, ticaretin ve kültürel işbirliğinin arttığı, savaşların ve göçlerin neden olduğu zorunluluk ve iyi ilişkilerin getirdiği yakınlaşma dolayısıyla neredeyse sınırların kalktığı dünyamızda insanlar artık hızla iki dilli, üç dilli kısaca çok dilli olmaya başladılar. Aslında bu durum yani birçok insanın birden fazla dil sahibi olduğu gerçeği bilinmekteydi, ancak son yıllarda bu insanlar birbiriyle sık karşılaşmaya başlamaları sebebiyle dile getirilmeye başlandı. Şimdi daha iyi anlaşılması için örneklendirelim. Ülkemizde yaşayan etnik kökeni farklı Türk vatandaşlarının sahip olduğu dilleri konumuz için örnek verebiliriz. Arap kökenli bir Türk vatandaşının "birinci dili" yani "ana dili" Arapçadır, "ikinci dili” ise yani "ülke dili, resmi dili" Türkçedir. Kürt kökenli birinin "birinci dili” Kürtçe, "ikinci dili” Türkçedir. Bu konuda daha geniş bilgi Buram

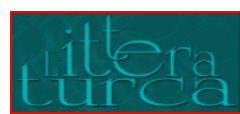

Journal of Turkish Language and Literature

Volume:2, Issue: 1, Winter 2016, (311-322)

Doi Number: 10.20322/lt.15463 
ve Yüksel Çak'ın(2012) “Türkiye'de Diller ve Etnik Gruplar” adlı kitabında bulunabilir. Başka ülkelerden örnek verelim. Almanya'da yaşayan Türk kökenli bir Alman vatandaşının "birinci dili” Türkçe, "ikinci dili” Almancadır, Almanca onun için yabancı dil değildir. Bu tezimizi illeri (2007: 578), Bausch/Christ/Krumm (2007) üçlüsünün Yabancı Dil Öğretimi El Kitabı'nda (Handbuch Fremdsprachenunterricht) yer alan Türkçe (Türkisch) başlıklı yazısında Almanya'da yaşayan Türk azınlığın birinci dillerinin yani ana dillerinin, aile dillerinin Türkçe, ikinci dillerinin ise Almanca olduğunu ifade ederek desteklemektedir. Yunanistan'da yaşayan Türk kökenli bir Yunan vatandaşının "birinci dili” Türkçe, ama "ikinci dili" Yunancadır. Yine Türkiye'de yaşayan Rumların "birinci dilleri” Rumca, Ermenilerin Ermenice ve her iki grubun “ikinci dilleri” ise Türkçedir. Bir başka örnek Amerika'da yaşayan Almanların "birinci dilleri” Almanca, Fransızların Fransızca ama her iki toplumun “ikinci dilleri” Ingilizcedir. Amerika'da yaşayan İngilizlerin hem "birinci dilleri” hem de "ikinci dilleri” İngilizcedir. Bizim ülkemizde de Türk kökenlilerin birinci ve ikinci dilleri aynıdır yani Türkçedir. Burada verilen örneklerden de görüleceği gibi etnik kökeni farklı olan kişilerde dilbilimi terminolojisinde bilingualizm adı verilen "ikidillilik" olarak ifade edilen özelliğe rastlıyoruz. Ancak bu konuyu ileride bir başka yazımızda “ikinci dil, iki dillilik, yabancı dil” başlığıyla daha geniş bir şekilde ele alacağımız için bu yazımızda konuyu dağıtmamak adına fazla detaylandırmıyoruz.

Son söz olarak, yazımızın konusu olan "ana dil” ve "ana dili" kavramlarının günlük hayattaki konuşmalarda, gazete, dergi ve kitaplarda, radyo ve televizyonlarda, siyasilerin konuşmalarında kısaca dilcilerin ve dilbilimcilerin dışındakilerin kullanımlarında karışıklık ve hatalı kullanım olduğunu söylemiştik. Bu hatalı kullanımları somut örneklerle ortaya koyduk. Hatalı kullanılan bu kavramların yerine, yani "ana dili" yerine "birinci dil”, "ana dil” yerine "ikinci dil” kavramlarının kullanılmasını önerdik. Ancak bu şekilde bir kullanımla yanlış kullanımın önlenebileceğini düşünüyoruz. Ayrıca bu tür adlandırmanın ve kullanımın Avrupa Birliği Dil, Eğitim ve Öğretim Programları ile de uyum sağladığını ve gelecekte Avrupa Birliğine tam üye olma sürecinde de ülkemiz için bir kolaylık olacağını umuyoruz.

\section{KAYNAKÇA}

Aksan, Doğan (1990). Her Yönüyle Dil, Ana Çizgileriyle Dilbilim 1, Ankara: TDK Basımevi.

Bausch, Karl-Richard - Christ, Herbert - Krumm, Hans-Jürgen (2007). Handbuch Fremdsprachenunterricht, A.Francke Verlag,Tübingen und Basel.

Buran, Ahmet - Yüksel Çak, Berna (2012). Türkiye’de Diller ve Etnik Gruplar, Ankara: Akçağ Yayınları.

Demircan, Ömer (1990). Yabancı Dil Öğretim Yöntemleri, İstanbul: Ekin Eğitim-Yayıncılık ve Dağıtım.

Duden (1985). das Bedeutungswörterbuch Band 10, Dudenverlag, Mannheim-Leipzig-Wien-Zürich.

Ergin, Muharrem (2000). Türk Dil Bilgisi, İstanbul: Bayrak Basım/Yayım/Tanıtım.

Gencan, Tahir Nejat (1997). Dilbilgisi, İstanbul: Kanaat Yayınları.

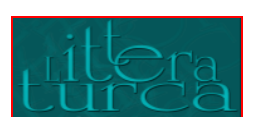

Journal of Turkish Language and Literature

Volume:2, Issue: 1, Winter 2016, (311-322)

Doi Number: $10.20322 /$ lt.15463 
Hengirmen, Mehmet (1999). Dilbilgisi ve Dilbilim Terimleri Sözlüğü, Ankara: Engin yay.

Illeri, Esin,"Türkisch", (Ed. Karl-Richard Bausch, Herbert Christ, Hans-Jürgen Krumm), Handbuch Fremdsprachenunterricht, A.Francke Verlag,Tübingen und Basel.

Klein, Wolfgang (1984). Zweitspracherwerb - Eine Einführung, Athenäum Verlag, Königstein.

Koç, Nurettin (1992). Açıklamalı Dilbilgisi Terimleri Sözlüğü, İstanbul: İnkılap Kitabevi.

Korkmaz, Zeynep (1992). Gramer Terimleri Sözlüğü, Ankara: TDK Yayınları 575.

Oomen-Welke, Ingelore, "Muttersprachenunterricht und Fremdsprachenunterricht", (Ed. KarlRichard Bausch, Herbert Christ, Hans-Jürgen Krumm), Handbuch Fremdsprachenunterricht, A.Francke Verlag,Tübingen und Basel.

Şahin, Veysel (2014). Bilge Kadının Aynadaki Yüzü (Halide Edip Adıvar’ın Romalarında Yapı ve İzlek), Ankara: Akçă̆ Yay.

Topaloğlu, Ahmet (1989). Dil Bilgisi Terimleri Sözlüğü, İstanbul: Ötüken Neşriyat.

Türkçe Sözlük (2005). Ankara: TDK.

Vardar, Berke (1988). Açıklamalı Dilbilim Terimleri Sözlüğü, İstanbul: ABC Tanıtım Basımevi.

Wahrig, Gerhard (1980). Deutsches Wörterbuch, Mosaik Verlag.

http://tdkterim.gov.tr/bts/

http://www.tdk.gov.tr/index.php?option=com_bilimsanat\&arama=kelime\&guid=TDK.GTS.56a7ccd1d5d815.06 569791(TDK Bilim ve Sanat Terimleri Ana Sözlüğü)

http://de.wiktionary.org/wiki/Hauptsprache

http://www.turkishstudies.net/Makaleler/1911810174_sagirmukim.pdf

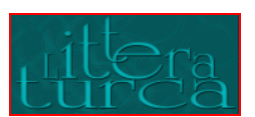




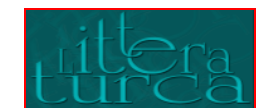

Journal of Turkish Language and Literature Volume:2, Issue: 1, Winter 2016, (311-322)

Doi Number: $10.20322 /$ It.15463 